Recibido: 9 marzo 2016 Aceptado: 1 julio 2016 Publicado: 29 julio 2016 Cita: Smith, D. (2016). «Social factor comparisons of noun and verb insertion patterns in Spanish and English bilingual clauses». Normas 6, 69-76. doi: 10.7203/Normas.6.8153

\section{Social factor comparisons of noun and verb insertion patterns in Spanish and English bilingual clauses}

\author{
COMPARANDO LOS FACTORES SOCIALES \\ DE LOS PATRONES DE INSERCIÓN DE \\ SUSTANTIVOS Y VERBOS EN LAS \\ CLÁUSULAS BILINGÜES ESPAÑOL/INGLÉS
}

\section{Daniel Smith \\ Clemson University}

Abstract:

This paper compares noun and verb insertion in bilingual clauses in a Spanish and English bilingual data corpus collected in northeast Georgia (U.S.A.). Even though Myers-Scotton and Jake (2014) have given grammatical reasons why verbs theoretically can be as easily inserted as nouns, most bilingual data corpora, from many different language contact settings, show that far more nouns than verbs of one language are inserted into clauses of the other language. The northeast Georgia Hispanic community data set examined here is no exception. Analysis of the northeast Georgia data reveal that some social factors are associated with higher inserted verb use. Children, who have more English proficiency in general than adults, insert more verbs into bilingual clauses than adults. Female gender, higher socio-economic status, and other than Mexican national origin are also associated with higher rates of verb insertion.

keywords: bilingualism, language contact, codeswitching matrix language, embedded language

\section{Resumen:}

Esta investigación compara la inserción de verbos en cláusulas bilingües en un corpus de datos recogidos en el noreste de Georgia (EEUU). Aunque han explicado gramaticalmente Myers-Scotton y Jake (2014) por qué los verbos en teoría pueden ser insertados tan fácilmente como los sustantivos, la mayoría de los datos bilingües, de muchos lugares donde hay bilingüismo, muestra que muchos más sustantivos de una lengua se insertan en las cláusulas de la otra lengua. Los datos de la comunidad hispana del noreste de Georgia que se estudian aquí no son ninguna excepción. El análisis de estos datos revela que hay factores sociales asociados con la inserción de los verbos. Los niños, que tienen más competencia en el inglés en general que los adultos, insertan más verbos en las cláusulas bilingües que los adultos. El género femenino, el estatus socioeconómico más alto y el origen nacional no de México también se asocian con el uso de más inserción de verbos.

Palabras clave: bilingüismo, contacto de lenguas, alternancia de códigos, lengua matriz, lengua insertada 
This study examines the discrepancy between noun and verb insertions in bilingual language contact. Analysis of bilingual language contact shows that nouns from one language are frequently inserted into sentences of another language. The same analysis shows that verbs are much more rarely inserted in bilingual sentences as compared to nouns. Even when there is the option for inserting or borrowing verbal nouns, for example in 'do' expressions, the borrowing and codeswitching (CS) of verbs is much less than that of nouns. In this paper verb and noun insertions are explained within the MLF, 4-M, and Abstract Level models (Myers-Scotton 2002, Myers-Scotton and Jake 2014).Myers-Scotton and Jake (2014) have shown that verbs can be inserted similar to nouns and that grammatical restrictions for verbs are more flexible than once thought.In light of this finding, the present study compares noun and verb insertion patterns in a Spanish and English bilingual data corpus collected in northeast Georgia (U.S.A.) along with social factors associated with these patterns in order to shed additional light on the discrepancy between verb insertions and noun insertions.

\section{THE MLF , 4-M, AND ABSTRACT LEVEL MODELS}

Myers-Scotton's MLF and 4-M models help to explain the appearance of single nouns and verbs from one language in a clause of phrase of another language. The 4-Morpheme (4-M) model (MyersScotton and Jake 2000a,b; Myers-Scotton 2002) classifies the morphemes of all human languages into four classes: (1) content morphemes and three types of system or grammatical morphemes, (2) early system morphemes, (3) late system bridge morphemes, and (4) late system outsider morphemes.According to Myers-Scotton's (1993 [1997], 2002) Matrix Language Frame (MLF) model, in a language contact setting, the matrix language (ML) provides most of the system morphemes, especially the late ones, but content morphemes may freely come from either language and content morphemes from one language which are insterted into clauses of another langauge are embedded language (EL) morphemes. Bilingual data sets in previous research (for example Jake 1998, Wei 2000, Smith and Morales 2013) support these models. This asymmetry is also related to which language is the matrix language and the crucial difference between early system morphemes and late system morphemes.

The Abstract Level model (Myers-Scotton 2002, 2014, Myers-Scotton and Jake 1995) extends the explanation of the production of single nouns and verbs in bilingual phrases and clauses by proposing three levels of "abstract lexical structure":(1) "lexical-conceptual structure," theextralinguistic semantic and pragmatic content coded into a lexical item; (2) "predicate-argument structure," the structure which relates lexical items to each other in phrase and sentence structure; and (3) "the level of morphological realization patterns," the level of morpheme realization in phonological form of the previous underlying levels.Content morphemes such as nouns and verbs are directly elected at the first abstract level of lexical-conceptul structure.

\section{THE GRAMMATICAL FACTORS OF EL VERB INSERTION COMPARED TO EL NOUN INSERTION}

The content portion of verbs as well as nouns (content morphemes in the 4-M model) can be embedded into an ML under the MLF model. Yet EL nouns are inserted much more frequently than verbs.According to Myers-Scotton and Jake (2014), EL nouns are so frequent because they are retrieved, within the Abstract Level model, from the mental lexicon at the earliest level of abstract structure in language production, the lexical-conceptual level, and thus "an EL noun need not match an $\mathrm{ML}$ counterpart at the levels of predicate-argument structure and morphological realization patterns." Verbs typically reference more of the rest of the structure of each sentence than do nouns; thematic roles are assigned by verbs; therefore "one prediction is that switching a verb should carry a higher production cost than a noun" because, as in Myers-Scotton (1993) and Myers-Scotton \& Jake (1995), the MLF model orignally included verbs checking "congruence" with the ML beyond the lexical-conceptual level.Myers-Scotton and Jake (2014) now think that, like EL nouns, "only the lexical-conceptual structure of EL verbs is checked for congruence with the ML," and they hypothesize "that in CS within a clause, only EL verbs which are nonfinite occur in an ML frame" and that "the form of the EL verb is nonfinite or ML morphology is added to an EL verb that allows it to be integrated into the ML frame." 
Therefore it remains unclear why so few EL verbs are inserted as compared to nouns, both being content morphemes (under the 4-M model), and every clause requires a verb even if it does not require an overtly expressed noun. This is especially true in a language like Spanish, a pro-drop language, in which neither subject nouns nor pronouns are required.The data of this study is the result of Spanish English contact, and the majority of the data involves the insertion of English content (noun or verb) morphemes into Spanish MLs.

Several bilingual data sets show more EL nouns than EL verbs inserted from one language into sentences of another language, even though some bilingual sets show a higher percentage of EL verbs as compared to those in other bilingual sets. In Pfaff's (1979) Spanish-English data, there are 71 EL verb insertions as compared to 818 EL noun insertions. In Poplack's (1980) Spanish-English data, there are $13 \mathrm{EL}$ verb insertions and $13 \mathrm{EL}$ verb phrase insertions as compared to $141 \mathrm{EL}$ noun insertions. This account doesn't tell which language is the EL, but English is assumed to be the EL.In Okasha's (1999) Arabic-English data there are $31 \mathrm{EL}$ English verb insertions as compared to $977 \mathrm{EL}$ English noun insertions. ${ }^{6}$ In Backus (1992) Dutch-Turkish data, EL Dutch nouns are slightly over two times as frequent as verbs, a high measure of EL verbs compared to the other data sets. However, in Backus (1996) there are only 15 EL Dutch verbs in 259 intrasentential codeswitches, a much lower number.In Treffeers-Daller's (1994) Dutch-French data EL French nouns account for $58.4 \%$ of EL insertions as compared to $8.9 \%$ of EL French verb insertions. In Myers-Scotton and Bernsten's (1995) Acholi-English data, there were 89 EL English nouns and noun phrases as compared to 48 EL English verbs, 10 of these being subject NP gerunds.In Myers-Scotton's (1993) Swahili-English data, English EL verbs occur over one half as frequently as EL English nouns, another high measure of EL verbs compared to most of the other data sets.

\section{5}

\section{DESCRIPTION OF THE POPULATION OF THE SPEAKER DATA}

The Spanish/English bilingual noun and verb insertion patterns discussed in this paper come from data collected in a northeast Georgia community (Habersham, Banks, and Stephens Counties) of Hispanics from Mexico, South and Central America, and the Caribbean, who immigrated to Georgia from 1980 to 2000.Data from naturally-occurring conversations by 56 children and adults of both genders are analyzed within Myers-Scotton's MLF model. Language patterns were identified, including monolingual Spanish and English turns, codeswitched turns, and turns showing convergence (morphemes from one language with abstract grammatical structure from the other). In the larger study (Smith 2002, 2006) from which this study is taken, tokens of each type (per sentence or short conversational turn) were counted per informant. The language patterns identified include EL single word or morpheme insertions, including nouns and verbs.

\section{EL VERB INSERTION COMPARED TO EL NOUN INSERTION IN THE NORTHEAST GEORGIA DATA WITH AGE AND GENDER ASSOCIATIONS}

In the data of this study there are $13 \mathrm{EL}$ verb insertions identified ${ }^{7}$, as shown in Table 1, and $102 \mathrm{EL}$ noun insertions identified ${ }^{8}$, as shown in Table2. Of the $13 \mathrm{EL}$ verb insertions, there are 11 English verbs inserted into a Spanish ML and 2 Spanish verbs inserted into an English ML.Of the 102 noun insertions, there are 98 English nouns inserted into a Spanish ML and 4 Spanish nouns inserted into an English ML.These numbers are similar to the data in the other studies mentioned above.

As seen in Table 1, children speakers inserted 12 out of the $13 \mathrm{EL}$ verbs into Spanish-English bilingual clauses.A majority of these children were females.Examples (1) and (2) are instances of EL

\footnotetext{
${ }^{6}$ The division of Okasha's (1999) data into generations is interesting because of the more frequent verb insertions in Generation 1 as compared to Generation 2, the opposite of what is shown in our data.Does increased English proficiency lead to less switching of verbs in Okasha's data set? In our data it seems to lead to more verb insertions.

${ }^{7}$ In the EL analysis of this study the investigator counted verb insertions that were made by children who were not absolutely identified as to which child. Even though the transcript noted they were children, from the tapes the investigator had noted in the original transcript that he couldn't tell exactly which child; if a one-to-one identification was not made he did not use those data in the original data analysis (Smith 2002), which accounts for why the EL verb insertions in the two analyses do not total exactly the same numbers.

${ }^{8}$ Unidentified verb insertions were not counted in the original analysis of the data; if unidentified noun insertions are counted there are even more than $102 \mathrm{EL}$ noun insertions. 
verb insertion found in the data in the speech of children.Example (1) also contains two EL noun insertions.

(1)

Puches play y luego le pones stop.

'You push play and then you push stop.'

(utterance of a male child talking about the tape player used for recording the speech data)

(2) No estaba leyendo, sólo estaba jugando, estaba clicking sólo lo que quería. (utterance of a female child).'He was not reading, he was just playing, he was clicking only what he wanted to.

Among adult speakers, also as seen in Table 1, only one female adult inserted an EL verb. The only insertion by an adult was the cheque- insertion, as seen in Example (3), and it is probably one of the most common verbs inserted in Spanish English contact data, making it virtually a borrowing.

(3) Te está diciendo que si está asegurado la casa por esta cantidad de dólares, está bien o no, tú chequéalo, y el contrato dado es del día diez y ocho. (utterance of a female adult). 'He is telling you that if the house is insured for this number of dollars, it is ok or not, you check it, and the contract given is from the date of the 18th.'

Tables 1, 2, and 3 show that children do most of the switching of all types of morphemes.From Tables 1 and 2 we note that children speakers switch both nouns and verbs.But nouns are more frequently inserted by children than by adults.Sentences containing all single word or morpheme insertions, including mostly nouns, are also used by adults, as seen in Table 3, but mostly by children, and among adults, mostly female adults.Younger females uttered the most EL insertions in bilingual clauses, followed by younger males, then older females, with older males having the lowest number of EL insertions. Therefore, younger age and female gender (especially younger females) are more closely associated with EL insertions than older age and male gender.

Table 1. EL verb insertions in the data

\begin{tabular}{|c|c|c|}
\hline \multicolumn{3}{|c|}{ English EL verb insertion into Spanish ML } \\
\hline 7 & $\begin{array}{l}7 \text { instances of: } \mathrm{PUCH}=\text { 'push' with Spanish system } \\
\text { morphemes attached (puchalo, } 4 \text { puchen, puches, puchando) }\end{array}$ & $\begin{array}{l}\text { produced by children } \\
3 \text { puchen - female } \\
\text { puches - male } \\
\text { puchalo-female } \\
\text { puchen-female??? } \\
\text { puchando-female??? }\end{array}$ \\
\hline 1 & $\begin{array}{l}\mathrm{CHEQUE}_{\mathrm{(}} \text { (chequealo) } \\
=\end{array}$ & produced by adult female \\
\hline 2 & $\begin{array}{l}2 \text { instances of: estaba CLICKING = 'he was clicking' used as } \\
\text { present participle }\end{array}$ & $\begin{array}{l}\text { produced by children } \\
\text { female }\end{array}$ \\
\hline 1 & es BACKING = 'he is backing up?' used as present participle & $\begin{array}{l}\text { produced by children } \\
\text { male }\end{array}$ \\
\hline \multicolumn{3}{|c|}{ Spanish EL verb insertion into English ML } \\
\hline 1 & I don't ENTENDO = 'I don't understand.' & $\begin{array}{l}\text { produced by children } \\
\text { male??? }\end{array}$ \\
\hline 1 & no good, ES no good ='no good, it's no good.' & $\begin{array}{l}\text { produced by children } \\
\text { male }\end{array}$ \\
\hline \multicolumn{3}{|c|}{$\begin{array}{l}\text { Total EL verb insertions } \\
13\end{array}$} \\
\hline
\end{tabular}

\footnotetext{
${ }^{9}$ The '???' symbol here indicates that a positive gender identification was not made for three instances, but a majority were positively identified as female children and two of the three with uncertain gender idenfications were most likely also females, as evidenced from the context of the conversations in the transcript. 
Table 2.EL noun insertions in the data (not counting pronoun insertions)

\begin{tabular}{|l|l|}
\hline English $\mathrm{EL}$ noun morpheme into Spanish $\mathrm{ML}$ \\
\hline 98 & many produced by both children and adults, but mostly by children \\
\hline Spanish EL noun morpheme into English ML \\
\hline 4 & 3 produced by children, only 1 by an adult female \\
\hline 102 total & \\
\hline
\end{tabular}

Table 3.All single word or morpheme insertions, including verbs and nouns

\begin{tabular}{|c|c|c|c|}
\hline \multicolumn{4}{|l|}{ Gender/Age } \\
\hline & Engish EL in Spanish ML & Spanish EL in English ML & \\
\hline male children & 40 & 9 & $\begin{array}{l}\text { Total for male children } \\
-49\end{array}$ \\
\hline $\begin{array}{l}\text { male } \\
\text { adults }\end{array}$ & 10 & 0 & $\begin{array}{l}\text { Total for male adults - } \\
10\end{array}$ \\
\hline female children & 66 & 4 & $\begin{array}{lrr}\text { Total for } & \text { female } \\
\text { children - } 70 & \\
\end{array}$ \\
\hline female adults & 44 & 1 & $\begin{array}{l}\text { Total for female adults } \\
-45\end{array}$ \\
\hline
\end{tabular}

\section{OTHER SOCIAL FACTORS ASSOCIATED WITH THE EL VERB AND EL NOUN INSERTION PATTERNS}

In the larger study from which these data are taken, children of either gender and females of both age groups report higher English use and Spanish influenced by English than older or male informants in general.Also, children have more exposure to English than adults due to children's attendance in schools in the U.S. (Smith 2002, 2009). English proficiency is associated with switching both nouns and verbs, but it is even more evident regarding verbs, since only one example was identified in the data from an adult speaker.The much larger number of switched EL nouns in comparison to switched EL verbs points out that even limited English proficiency allows for noun insertion and greater English proficiency promotes the greater possibility of more noun and more verb switching.

Previous analyis of the same data (See Smith 2002, 2006, 2009.) shows that more use of English and mixing Spanish with English in general is associated more with children than with adults, more with females than with males, and more with higher socio-economic status than with lower socioeconomic status and more with non-Mexican than Mexican region of origin. The adult speaker, college educated and from Peru, who produced the EL verb insertion in Table 1, was a female, nonMexican, and of higher socio-economic status.Another instance of an EL verb insertion, in Example (4), is from a conversation with myself and another adult female, also non-Mexican and of higher socio-economic status, in the Hispanic community of this study; she is from Peru and college educated.Her utterance, which also contains an EL noun insertion, was immediately followed by her own laughter and her verbal reference to the EL verb send insertion she had uttered, indicating that she had inadvertently inserted the English verb; she considered it to be a slip of the tongue.She did not seem to be nearly as concerned about the EL noun insertion email, which is relatively common in the speech of the community. However, her attitude to her own utterance is typical of many who consider most any form of Spanish and English mixing to be 'bad Spanish'. On the other hand, children, by nature, do not suffer from this inhibition.

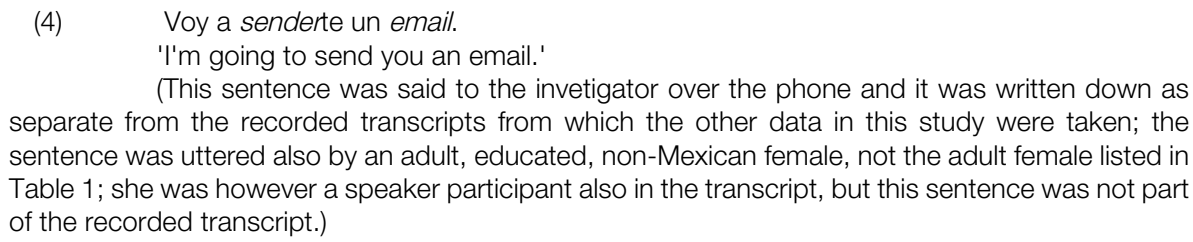


This study shows how many EL verb insertions are uttered in a Spanish English data corpus, compared to EL noun and all other insertions with associated social factors. EL verbs are much more infrequently inserted into bilingual sentences than are nouns in the northeast Georgia Spanish English bilingual data examined here as well as across many other bilingual language corpora.EL verbs theoretically should be just as easily inserted as EL nouns, since attached system morphemes are assigned after their direct election at the abstract lexical-conceptual level.EL verbs however are inserted in numbers far below that of EL nouns. However, the data examined here does show that children, mostly female, insert verbs much more frequently than do adults, and that female adults insert single words or morphemes in general more than do male adults. Non-Mexican females of higher socio-economic status had a tendency to mix more English with Spanish in general in the data as a whole, and the only adults who inserted an EL verb were also non-Mexican females of higher socio-economic status.Since children have more exposure to English than adults in the community of the data, English proficiency is associated with more EL insertions and with more EL verb insertions. Increased proficiency in the EL language may have grammatical explanations which should be investigated.

Comparing percentage of verb insertions in different language pairs and how they are integrated in other types of language mixing also needs to be examined. It would be interesting to investigate the fact that some language pairs show much higher percentages of EL verb insertions than other language pairs.Additionally, since this study (and that of Myers-Scotton and Jake 2014) only considers classic CS but not other forms of contact such as grammatcial convergence, further investigation of the social and grammatical factors of other forms of language contact such as convergence and attrition may also show differences in verb and noun integration, which, together with the findings here, will serve to widen the scope initiated in this study.

\section{REFERENCES}

Backus, A. (1992): Patterns of language mixing, a study of Turkish-Dutch bilingualism. Weisbaden: Otto Harrassowitz.

Backus, A.(1996): Two in one: Bilingual speech in Turkish immigrants in The Netherlands. Tilburg: Tilburg University Press.

Jake, J. (1998): Constructing interlanguage: building a composite matrix language. Linguistics 36.2: 333-382.

Myers-Scotton, C. (1993): Duelling languages: Grammatical structure in codeswitching. Oxford: Oxford University Press. [2nd edn. in 1997, with new "Afterword".]

Myers-Scotton, C. (2002): Contact Linguistics: Bilingual Encounters and Grammatical Outcomes. Oxford: Oxford University Press.

Myers-Scotton, C., \& Bernsten, J.(1995): AcholiEnglish corpus (unpublished). University of South Carolina.

Myers-Scotton, C. , \& Jake, J. (1995): «Matching lemmas in a bilingual language competence and production model: Evidence from intrasentential codeswitching», Linguistics, 33, 981-1024.

Myers-Scotton, C., \& Jake, J. (2000a): «Four types of morpheme: Evidence from aphasia, code switching, and second-language acquisition», Linguistics 38.6:1053-1100.

Myers-Scotton, C., \& Jake, J. (2000b): «Testing the 4-M model: An introduction. International», Journal of Bilingualism, 4.1: 1-8.

Myers-Scotton, C., \& Jake, J.(2014): «Nonfinite verbs and negotiating bilingualism codeswitching: Implications for a language production model», Bilingualism: Language and Cognition, 17.3: 511-525.

Okasha, M. (1999): Structural constraints on Arabic-English codeswitching: Two generations. Ph.D. dissertation, University of South Carolina.

Pfaff, C. (1979): «Constraints on language mixing: Intrasentential code-switching and borrowing in Spanish/English», Language, 55, 291-318.

Poplack, S. (1980): «Sometimes l'll start a sentence in Spanish y termino en español», Linguistics, 18, 581-616.

Smith, D. J. (2002): Patterns of variation in Spanish/English bilingualism in northeast Georgia. Austin, TX: University of Texas dissertation.

Smith, D. J. (2006): «Thresholds leading to shift:Spanish/English codeswitching and convergence in Georgia, USA», The International Journal of Bilingualism 10(2), 207240.

Smith, D. J. (2009): "Spanish and English gender/age variation in Georgia», Hipertexto, Univ. of Texas-Pan American, v.10(summer), 90-111, http://www.utpa.edu/dept/modlang/hipertexto I

Smith, D. J., \& Morales, M. (2013): «Second language acquisition of Spanish by morpheme type: The 4-M model», Southern Journal of Linguistics 37(1). 
Social factor comparisons of noun and verb insertion patterns in Spanish and English bilingual clauses | Daniel Smith

Treffers-Daller, J. (1994): Mixing two languages: French-Dutch contact in a comparative perspective. Berlin: Mouton de Gruyter.

Wei, L. (2000): «Unequal election of morphemes in adult second language acquisition», Applied Linguistics, 21.1: 106-140. 
Social factor comparisons of noun and verb insertion patterns in Spanish and English bilingual clauses | Daniel Smith 